\title{
Vaikų gripas - 2009 metų pamokos
}

Laimutė Vaidelienė, Dovilè Grinkevičiūtè

LSMU MA Vaikų ligų klinika

Reikšminiai žodžiai: pandeminis gripas, H1N1, vaikai, epidemiologija, klinika, gydymas.

Santrauka. 2009 m. pasaulyje paplitęs gripo H1N1 virusas kol kas nepadare tiek žalos, kiek buvo tikètasi. Pandemija prasidejo stiprios ekonomikos šalyse, gripas nebuvo toks pavojingas vyresnio amžiaus žmonėms kaip 1918 metais - jau buvo susiformavęs imunitetas, antivirusiniai vaistai veikè, ir dauguma sirgusiujų patyrẻ ne itin stiprius simptomus. Vis dèlto 214-oje pasaulio šalių užregistruota 1483520 gripo atvejų ir laboratorijoje patvirtinti 18036 mirties nuo pandeminio gripo atvejai.

Lietuvoje nuo 2009 m. spalio iki 2010 m. kovo ménesio gripu persirgo 59 tūkst. suaugusiujų ir vaiku, laboratorijoje patvirtinta 810 susirgimų $A(H 1 N 1)$ gripu, užregistruoti 23 mirties atvejai.

Kauno medicinos universiteto klinikose (KMUK) ir Kauno 2-ojoje klinikinejje ligonineje 2009-11-06-12-22 nuo klinikiniu gripo simptomu gydyti 545 vaikai. 16 vaiku gydyti intensyviosios terapijos skyriuje, 6 vaikai mire nuo įtariamo gripo ar jo komplikacijų, laboratorijoje H1N1 virusas patvirtintas dviem iš jų. Klinikiniai Kaune gydytų vaikų gripo simptomai beveik nesiskyrė nuo PSO skelbiamy simptomų: karšciavimas buvo 99,45 proc. atveju, kosulys - 80,37 proc., sloga - 45,32 proc., galvos skausmas $-26,97$ proc., gerklès skausmas - 18,17 proc. atvejų. $2009 \mathrm{~m}$. H1N1 gripui būdingas vemimas pasireiškè 25,32 proc., viduriavimas 8,81 proc. ligoninėse gydytų vaikų. 18,7 proc. vaikų buvo citopenijos požymių: leukocitopenija - 11,7 proc., granuliocitopenija - 9,1 proc., trombocitopenija - 12,5 proc. vaikų. Šiems vaikams, palyginti su citopenijos neturëjusiais, dažniau nustatyta bakterinè infekcija: 11,1 proc., palyginti su 1,9 proc. $(x 2=16,4 ; p<0,05)$. Gripas komplikavosi pneumonija 134 (24,59 proc.) stacionare gydytiems vaikams.

Sergant gripu, galimos sunkios komplikacijos, kurios dažniausiai pasireiškia kvèpavimo sistemoje ir sukelia kvèpavimo nepakankamumą, šoką bei mirti. Todèl didelès rizikos pacientams pagal $2010 \mathrm{~m}$. vasario mèn. atnaujintas PSO gripo gydymo rekomendacijas gydymas turi būti skiriamas nedelsiant. Geriamasis oseltamiviras ir inhaliuojamasis zanamiviras yra patvirtinti vaiku gripo gydymui ir profilaktikai. Per 48 val. nuo ligos pradžios pradèti skirti antivirusiniai vaistai sumažina ligos sunkumą ir trukmę. Šių metų patirtis rodo, kad ir vèliau pradètas antivirusinis gydymas gali būti naudingas. KMUK ir Kauno 2-ojoje KL oseltamiviru buvo gydyti 225 vaikai (41,3 proc.). Vaikams, kurių gripas komplikavosi bakterine infekcija, antibakterinis gydymas yra būtinas ir gali būti gyvybiškai svarbus. 249 (53,9 proc.) Kauno stacionaruose gydytiems vaikams skirta antibiotiku.

Vakcinacijos reikšme apsisaugoti nuo sezoninio ar pandeminio gripo yra neabejotina. Tačiau iš KMUK ir Kauno 2-ojoje KL gydytu vaikų tik 6 (1,1 proc.) buvo skiepyti nuo sezoninio gripo. Ekspertai teigia, kad tikètina antra pandeminio gripo banga. Tokiu atveju vakcinacijos klausimas taip pat išlieka aktualus.

Gripo virusai yra vieni iš svarbiausių ūminių kvėpavimo takų ligų sukèlejų. Pasaulyje kasmet gripu suserga milijonai žmonių ir kasmet registruojama mirties nuo gripo ar jo komplikacijų atvejų. JAV tyrëjų duomenimis, vidutinis su gripu susijusių mirties atvejų skaičius čia 1979-2001 metais buvo 41400 (95 proc. PI 27100-55700) [1]. Didžiausias mirtingumas nustatytas sergant $\mathrm{A}(\mathrm{H} 3 \mathrm{~N} 2)$ gripu, mažesnis - $\mathrm{B}$ gripu, trečioje vietoje $-\mathrm{A}(\mathrm{H} 1 \mathrm{~N} 1)$ gripas [2]
Nors daugiausia mirčių registruota vyresnių nei 65 metų žmonių grupejje, gripo virusas aprašomas ir kaip svarbus vaikų kvẻpavimo takų patogenas, sąlygojantis didelị kūdikių ir mažu vaikų sergamumą bei dažną hospitalizavimą. Pirmą kartą gripas paminètas dar prieš mūsų erą, Hipokrato laikais, tačiau pirmoji žinoma epidemija registruota tik 18 amžiuje. Praejjusiame šimtmetyje siautèjo keturios didelès gripo epidemijos, iš kurių di- 
1 lentelè. PSO 2010 m. gegužès mènesi paskelbti su A(H1N1) gripu susijusių mirčių duomenys kai kuriose šalyse

\begin{tabular}{lrrlrr}
\hline Valstybe் & $\begin{array}{r}\text { Mirčiú } \\
\text { skaičius }\end{array}$ & $\begin{array}{r}\text { Mirtys / } \\
\text { mln. gyv. }\end{array}$ & Valstybė & $\begin{array}{r}\text { Mirčių } \\
\text { skaičius }\end{array}$ & $\begin{array}{r}\text { Mirtys / } \\
\text { mln. gyv. }\end{array}$ \\
\hline JAV & 10837 & 35,28 & Estija & 16 & 9,7 \\
\hline Latvija & 34 & 13,73 & Prancūzija & 307 & 4,72 \\
\hline Kanada & 429 & 12,65 & Ukraina & 96 & 4,62 \\
\hline Vengrija & 119 & 11,86 & Lenkija & 175 & 4,51 \\
\hline JK & 412 & 6,68 & Vokietija & 226 & 2,75 \\
\hline Norvegija & 29 & 6,0 & Baltarusija & 7 & 2,07 \\
\hline Lietuva & 23 & 5,37 & Austrija & 5 & 0,6 \\
\hline
\end{tabular}

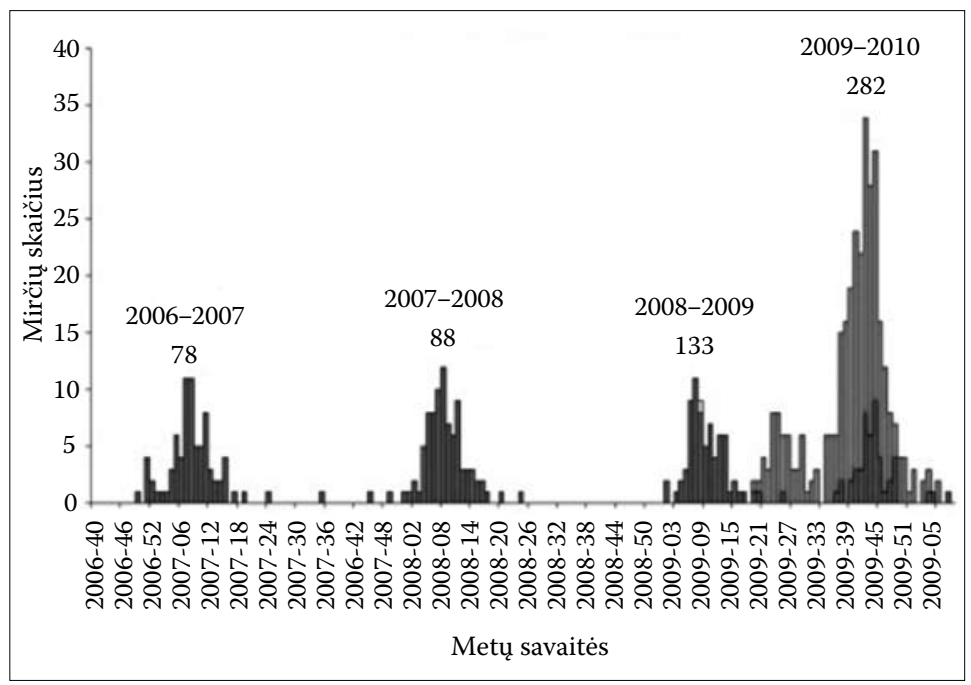

1 pav. Vaiku mirties nuo gripo atveju pasiskirstymas JAV 2006-2009 m.

džiausia - 1918-uju metų. Ispaniškasis gripas (H1N1) pirmoji pasaulinè pandemija, kai gripu persirgo $0,5 \mathrm{mlrd}$. žmonių, o mirè mažiausiai $21 \mathrm{mln}$. žmonių (galbūt net 50-100 mln.)., daugiausia jauni sveiki suaugusieji, du trečdaliai jų mirè keturių mènesių laikotarpiu [12, 13]. Sezoninio gripo epidemijos metu dažniausiai miršta kūdikiai (< 6 mèn.) ir pagyvenę žmonès (> $65 \mathrm{~m}$ ). Kodèl per 1918 m. pandemiją užsikrètė jauni žmonès, nėra visiškai aišku [3]. Manoma, kad tai susiję su labai stipriu jaunų žmoniu imuninès sistemos atsaku i nežinomą virusą, o tai sąlygojo labai stiprų uždegimą pažeistose vietose, dažniausiai kvépavimo takuose.

Biologinès gripo viruso savybės sudaro sąlygas naujoms jo padermèms atsirasti ir patekti ị žmonių populiaciją. Paprastai paukščių ir gyvūnų virusai mutuoja taip, kad gali užkrèsti žmogų. Kiaulių gripo virusas $\mathrm{H} 1 \mathrm{~N} 1$, sukeliantis kiaulèms kvèpavimo takų simptomus ir karščiavimą, išskirtas 1931 metais [14]. Jis panašus, bet ne identiškas ispaniškajam. Pavienių kiaulių gripo, kuriuo susirgo žmonès, atvejų užfiksuota JAV $1970 \mathrm{~m}$. Trejopas antigeninis persigrupavimas, kai virusas igijo žmogaus, kiaulių ir paukščiu A gripo genetinių savybių, nustatytas JAV 1998 m. 2005-2009 metais šios atmainos gripu JAV sirgo 12 pacientu $[5,15]$. 2009 metų balandžio 15-17 d. šis virusas nustatytas dviem vaikams iš Kalifornijos [4]. Nè vienas iš vaikų neturèjo kontakto su kiaulèmis $[4,5,6,7]$.

Labai greitai jis buvo identifikuotas Meksikoje, Ka- nadoje ir kitose šalyse. Dèl spartaus viruso plitimo PSO 2009 metų birželio ménesi paskelbè pirmąją nuo 1968 metuc gripo pandemiją [8]. Šiuo gripu, kaip ir 1918-aisiais, dažniausiai sirgo jaunesni nei 65 metų žmonès (amžiaus vidurkis - 5-24 m.), iš kurių beveik pusẻ - vaikai iki 18 metų $[3,9,10]$. Nors šio viruso virulentiškumas nedidelis, o infekcijos eiga palyginti nesunki, nèra žinoma, ar šis klinikinis fenotipas išliks ir per ateinanti gripo sezoną.

\section{EPIDEMIOLOGINIAI DUOMENYS}

Nuo A(H1N1) gripo pandemijos pradžios iki 2010 gegužès mẻn., PSO duomenimis, 214-oje pasaulio šalių užregistruota 1483520 gripo atvejų. Statistika labai netiksli, nes registruojami tik laboratoriškai patvirtinti H1N1 gripo atvejai. Mirčiu nuo pandeminio gripo taip pat registruota visose pasaulio šalyse. Nors kai kuriuose dokumentuose minima, kad pasaulyje nuo šio gripo galejo mirti 25174 žmonès, oficialiai PSO tinklalapyje skelbiama, kad iki 2010 metuc gegužès 9 d. laboratorijoje patvirtinti 18036 mirties nuo pandeminio gripo atvejai (1 lentelè) [16], iš jų 4638 - Europos valstybèse.

PSO dokumentuose pažymima, kad, kaip ir 1918 metais, H1N1 virusas visais atžvilgiais labiau paveikè jaunesnius žmones: jie dažniau sirgo, dažniau buvo hospitalizuojami, jiems dažniau prireikdavo gydymo intensyviosios terapijos skyriuje, daugiau jų mirè [18].

Nepavyko rasti pasaulinių vaikų mirštamumo nuo H1N1 gripo duomenų. JAV ligų kontrolès centras (angl. Centers for Disease Control and Prevention, CDC) skelbia, kad nuo 2009 balandžio iki 2010 gegužès mèn. užregistruoti 282 laboratorijoje patvirtinti vaikų iki 18 metų su A(H1N1) gripu susiję mirties atvejai (1 pav.). Du trečdaliai mirusių vaikų buvo vyresni nei 5 metų [17]. Palyginti su pastarųjų 5 gripo sezonų vaikų mirtingumu, 2009-2010 $\mathrm{m}$. jis padidejo 4 kartus.

JAV duomenimis, gripo pandemijos laikotarpiu daugiausia buvo hospitalizuojami vaikai, tačiau mirtingumas šioje amžiaus grupejje buvo mažiausias (2, 3 lentelès).

\section{VAIKŲ H1N1 GRIPO KLINIKINIAI YPATUMAI}

2009 metu gripo pandemijos metu sirgusiems vaikams dažniausiai pasireiškė tipiški gripo simptomai: karščiavimas, kosulys, gerklès ir raumenų skausmai $[5,6,9,15]$. Daug daugiau vaikų nei suaugusiųjų vėmè ir viduriavo [5]. Neurologinès komplikacijos buvo retos. Teksase keturiems vaikams pasireiškè gripo simptomai, lydimi traukulių ar psichikos būklès pokyčių [31].

Aprašoma daug nedidelių imčių vaikų gripo tyrimų, vertinusiu klinikines H1N1 charakteristikas. Koliou su bendraautoriais aprašè pirmuosius vaiku gripo atvejus JAV ir nurodè, kad tipiški klinikiniai simptomai buvo karščiavimas (98 proc.), kosulys (96 proc.), rinorèja (79 proc.), gerklès skausmas (73 proc.), bendras silpnumas (68 proc.) ir galvos skausmas (57 proc.). Rečiau pasitaikè vėmimas, viduriavimas, konjunktyvitas ir artralgija.

Hackett su bendraautoriais aprašè Birmingeme (JK) hospitalizuotų 78 vaikų klinikinius simptomus ir, be dažniausiai pasitaikančiuc (karščiavimo, kosulio ir rinorejjos), 
paminėjo vėmimą su krauju, ausies ir krūtinės skausmus, šviesos baimę, krupą, celiulitą, apnèjos epizodus bei kitas gyvybei grèsmingas būkles [28]. Ju duomenimis, 15,8 proc. vaiku išsivystè bakterinès komplikacijos ir 8 proc. buvo gydyti intensyviosios terapijos skyriuje.

Lister su kolegomis apibendrino keturiuose JK intensyviosios terapijos skyriuose gydytuc 13 vaikų duomenis [29]. Vidutinis jų amžius buvo 9 metai, 5 iš jų - mirè. Dauguma šių vaikų turèjo lètinę plaučių patologiją ar imunodeficitą. Aštuoniems išsivystè šokas, tačiau tik vienam jis buvo sepsinis. Kita studija nagrinèjo 36 vaikų, mirusių JAV nuo gripo ar jo komplikacijų, ligos eigos ypatumus [30]. Vaikų mirtys sudarè 7,5 proc. visų mirčiu $(\mathrm{n}=477)$. Tik 7 (19 proc.) mirę vaikai buvo jaunesni nei 5 metų amžiaus. 67 proc. mirusių vaikų sirgo viena ar keliomis lètinėmis ligomis (dažniausiai astma) ar turèjo gretutinę patologiją (dažniausiai psichomotorinès raidos sutrikimų). 43 proc. mirusių vaikų gripą komplikavo bakterinè infekcija.

Dažniausiai aprašomi A(H1N1) gripo sukelti specifiniai laboratoriniai pokyčiai vaikams yra leukopenija (ypač limfopenija) ir trombocitopenija [6, 9]. Taip pat buvo nustatomas didelis laktatdehidrogenazès ir kreatinkinazès kiekis kraujo serume. Tipiškiausi krūtinès ląstos rentgeniniai pokyčiai - abipuse infiltracija ar skiltine pneumonija [9]. Dažnai aprašomi ir teigiami bakteriologiniai pasèliai A(H1N1) gripu sergantiems vaikams. Dažniausiai išskirti Streptococcus pneumoniae, Staphylococcus aureus ir Streptococcus pyogenes [30, 32].

Apibendrinusi naujausius duomenis apie $\mathrm{A}(\mathrm{H} 1 \mathrm{~N} 1)$, PSO nurodo pagrindinius pandeminio gripo klinikinius požymius vaikams mažėjančio dažnumo seka:

- padidejusi temperatūra (iki $39-40^{\circ} \mathrm{C}$ );

- gerklès ir galvos skausmas;

- sloga;

- kosulys;

- vėmimas;

- viduriavimas;

- nuovargis, raumenu skausmas;

- apetito stoka.

- Virusas pažeidžia gleivines ir vietini imunitetą, dèl to gali lengvai patekti bakterine infekcija. Gripas gali komplikuotis virusiniu pneumonitu ar bakterine pneumonija, otitu, sinusitu, limfadenitu, retai meningitu, perikarditu, miokarditu.

- Gripas gali pabloginti kitų lètinių ligų eigą.

Akcentuojama, kad dèl imuniteto prieš H1N1 neturëjimo ir dèl didesnès užsikrètimo tikimybès (nes lanko kolektyvus) maži vaikai priskiriami rizikos grupei susirgti gripu ir išsivystyti komplikacijoms. Nurodoma, kad jaunesniems vaikams gripo eiga gali būti netipinè ir pasireikšti bendrais virusinei infekcijai būdingais požymiais: krupu, bronchitu, pilvo skausmu, vėmimu ar diarẻja. Kūdikių gripas gali būti sunkiai atpažįstamas, simptomai nespecifiški ir panašūs ị bakterinès infekcijos. Vaikams iki 6 mèn. gripas gali pasireikšti mieguistumu, karščiavimu, blogu apetitu ir prastos mikrocirkuliacijos simptomais (blyškumas, marmuruotumas, šaltos galūnès, kt.). Dažniausia H1N1 gripo komplikacija virusinè ir bakterinè pneumonija (pavojingiausias bak-
2 lentelè. Su A(H1N1) gripu susijęs hospitalizavimas jvairiose amžiaus grupèse JAV

\begin{tabular}{cc}
\hline Gyventojų amžius & Hospitalizacijų sk. / 10 tūkst. gyv. \\
\hline Iki 4 metų & 7,3 \\
\hline $5-17$ metuc & 2,9 \\
\hline$>65$ metuc & 1,1 \\
\hline
\end{tabular}

3 lentelè. Su gripu A (H1N1) susijusių mirčių pasiskirstymas jvairiose amžiaus grupèse JAV

\begin{tabular}{cc}
\hline Gyventojų amžius & $\begin{array}{c}\text { Procentinė dalis nuo visuc } \\
\text { mirusiųjų }\end{array}$ \\
\hline Iki 4 metų & 2 proc. \\
\hline $5-24$ metuc & 16 proc. \\
\hline $25-49$ metuc & 41 proc. \\
\hline
\end{tabular}

terinis sukèlëjas - Staphylococcus aureus).

Jau minejome, kad pandeminiu gripu dažniau serga vyresni vaikai. Tačiau reikia turèti omenyje, kad populiacijoje cirkuliuoja ir sezoninis gripas, kurio komplikacijos daugiausia pasireiškia vaikams iki 5 metų amžiaus, rizika itin didelè vaikams iki $2 \mathrm{~m}$.

Pagal 2009 metu sveikatos apsaugos ministro ìsakymu Nr. V-536 patvirtintą sezoninio gripo diagnostikos, gydymo ir profilaktikos antivirusiniais vaistais metodiką, vaikai iki 5 metų amžiaus priklauso komplikuotų gripo formų rizikos grupei.

\section{LIETUVOS VAIKŲ, SIRGUSIŲ PANDEMINIU GRIPU, DUOMENŲ ANALIŻ்}

2009 metų gripo pandemijos Lietuvoje apibendrintą analizę pateikè 2010-04-14 Vilniuje vykusio Nacionalinio gripo forumo dalyviai [19]. Jų teigimu, situacija pasaulyje bei Europoje galèjo būti ir daug blogesnè:

- laimei, gripas prasidejo stiprios ekonomikos šalyse, ir tai lemè greitą informacijos sklaidą, ankstyvą ligos diagnozavimą;

- palyginti su 1918 m. gripu, šis gripas nebuvo toks pavojingas vyresnio amžiaus žmonèms - pastarieji jau turèjo imunitetą;

- virusiniai vaistai veiké;

- daugelis susirgusiųjų jautė ne itin stiprius simptomus, nors, buvo ir išskirtinių mirties atvejų, kai žmonès mirdavo per 48 valandas nuo pirmujuc simptomų atsiradimo.

Vis dèlto pabréžiama, kad 2009-2010 m. gripo sezono pradžia buvo neịprasta, nes gripo epidemija visoje Lietuvoje paskelbta gerokai anksčiau nei iprasta 2009 m. lapkričio 24 d. Nuo 2009 m. spalio iki 2010 m. kovo mènesio Lietuvoje gripu persirgo 59 tūkst. suaugusiųjų ir vaikų, tuo tarpu 2007-2008 m. - 18 tūkst., o 2008-2009 m. - tik 7 tūkst. gyventojų. Manoma, kad besimptome gripo forma galejo persirgti dar apie 30 proc., t. y. 90 tūkst. Lietuvos gyventojų. Lietuvoje nuo 2009 m. birželio iki $2010 \mathrm{~m}$. balandžio mèn. patvirtinta 810 susirgimų $\mathrm{A}(\mathrm{H} 1 \mathrm{~N} 1)$ gripu. Per tą laikotarpi užregistruoti 23 mirties atvejai, dauguma jų - nuo ligos komplikacijų. 


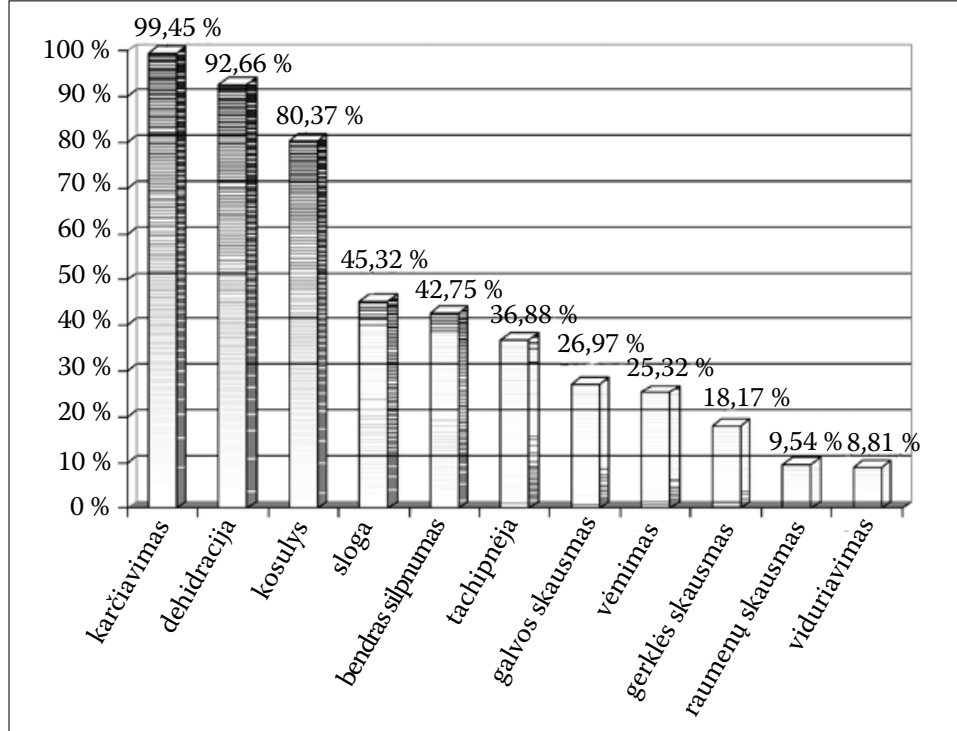

2 pav. Kauno ligoninėse gydytų vaikų klinikinių gripo simptomų pasiskirstymas

Nacionaliniame gripo forume pateikti ir kai kurie Lietuvos vaikų sergamumo gripu duomenys. Doc. Virginija Žilinskaitè pristatė Vilniaus apskrities duomenis, Vilniaus universiteto vaikų ligoninëje per didžiausią pandeminio gripo protrūkị Lietuvoje (45-51 metų savaitę) buvo hospitalizuoti 432 gripu sergantys vaikai: 15 proc. iš jų buvo kūdikiai, 76 proc. - vaikai nuo 1 iki 15 metu ir 9 proc. - 15-18 metu amžiaus jaunuoliai. 39 hospitalizuotiems vaikams reikejjo intensyviosios terapijos paslaugu, mirties atvejų nebuvo.

Docentė daro išvadą, kad gripo pandemijos metu daugiau vaikų susirgo, daugiau jų reikejjo hospitalizuoti, tačiau mirčių skaičius šioje amžiaus grupejje buvo mažesnis nei suaugusiųjų.

KMU Vaikų ligu klinikoje, vadovaujant doc. R. Kèvalui, taip pat atlikta gripu sirgusiu pacientu analizè. KMUK ir Kauno 2-ojoje KL 2009-11-06-12-22 laikotarpiu nuo klinikinių gripo simptomų gydyti 545 vaikai. Jų amžiaus vidurkis $-7 \pm 0,2 \mathrm{~m}$., vidutiné gydymo stacionare trukmé $-4,94$ $\pm 0,1$ d. Intensyviosios terapijos skyriuje gydyta 16 vaiku. Nuo įtariamo gripo ar jo komplikacijų mirè 6 vaikai. Tačiau tik vienam iš ju patvirtintas pandeminis H1N1 gripas. Dar vienam pacientui laboratoriškai patvirtintas sezoninis gripas, kitiems 4 vaikams gripas diagnozuotas tik kliniškai.

Kauno ligoninėse gydytų vaikų klinikinių gripo simptomų pasiskirstymas pateiktas 2 paveiksle. Jų dažnumas atitinka PSO duomenis.

Išanalizavus 545 gripu sirgusių Kauno ligoninèse gydytu vaiku laboratorinius tyrimus, nustatyta, kad beveik penktadaliui (18,7 proc.) buvo citopenijos požymių:

- Leukocitopenija (< 4 x 10\%/l) nustatyta 63 vaikams (11,5 proc.);

- Granuliocitopenija (< 1,5 x 109/1) - 47 vaikams $(8,6$ proc.);

- Trombocitopenija (< $\left.150 \times 10^{9} / \mathrm{l}\right)$ - 67 (12,3 proc.);

- Leukocitopenija patikimai dažniau nustatyta vyresniems vaikams $-10,1 \pm 0,7 \mathrm{~m}$. amžiaus, palyginti su $6,8 \pm 0,2$ metų vaikais, kuriems šių požymių nebuvo (p > 0,05);
- Šiems vaikams dažniau pasireiškè ir bakterinè infekcija: 11,1 proc., palyginti su 1,9 proc. $\left(\chi^{2}=16,4 ; \mathrm{p}\right.$ $<0,05)$

- Gripas komplikavosi pneumonija 134 (24,59 proc.) stacionare gydytiems vaikams. Kitos komplikacijos: sinusitas, otitas, limfadenitas, paratonzilinis abscesas, sepsis, sepsinis šokas.

20 proc. stacionare gydytų vaiku atlikti pasèliai patogeniniams mikroorganizmams nustatyti - 124 kraujo, nosiaryklès sekreto, tonzilių, trachejos sekreto, šlapimo, išmatų, likvoro pasèliai. Patogeniniai mikroorganizmai identifikuoti 14-oje pasèlių. Skrepliuose ir trachèjos sekrete dažniausiai nustatyta Staphylococcus aureus (3 atvejai) ir Streptococcus pneumonia (2 atvejai), po 1 atveji - Streptococcus pyogenes, Acinetobacter, Proteus, Pseudomonas. Šie rezultatai taip pat patvirtina pasaulyje atliktų tyrimuc rezultatus ir PSO rekomendacijas.

Antivirusinis gydymas oseltamiviru buvo paskirtas 41,3 proc. $(n=225)$ Kauno stacionaruose gydytų vaikų: KMU Vaikų ligu klinikoje - 83,41 proc. $(\mathrm{n}=123)$, Kauno 2 -ojoje $\mathrm{KL}-25,8$ proc. $(\mathrm{n}=103)$. Antibakterinis gydymas skirtas 249 (53,9 proc.) stacionare gydytų vaikų.

Pandemijos protrūkio metu H1N1 gripo viruso vakcinos Lietuvoje dar nebuvo, tačiau ir nuo sezoninio gripo skiepyti tebuvo tik 6 (1,1 proc.) stacionare gydyti vaikai.

\section{VAIKŲ GYDYMO YPATUMAI}

Sezoninio gripo gydymui ir profilaktikai tradiciškai vartoti rimantadinas, amantadinas pasirodè esą neefektyvūs pandeminio gripo metu. Pasaulio mastu paimtų daugiau nei 10 tūkst. klinikiniu mèginių tyrimai parodè, kad A(H1N1) gripo virusas jautrus neuraminidazių inhibitoriams osaltamivirui ir zanamivirui [23]. Tačiau 2009 spalio $9 \mathrm{~d}$. paskelbta apie pirmuosius viruso atsparumo oseltamivirui atvejus [23, 24]. Visi šie virusai turèjo tą pačią H275Y mutaciją, kuri sąlygoja atsparumą oseltamivirui, bet ne zanamivirui.

Geriamasis oseltamiviras ir inhaliuojamasis zanamiviras yra patvirtinti vaiku gripo (tiek sezoninio, tiek ir pandeminio) gydymui ir profilaktikai. Antivirusiniai vaistai mažina ligos sunkumą ir trukmę, tačiau efektyviausiai veikia, kai jų skiriama ligos pradžioje - geriausiai per 48 valandas. Nepaisant to, šių metų patirtis ir ypač sunkių gripo atveju gydymo rezultatai rodo, kad ir vèliau pradètas antivirusinis gydymas gali būti naudingas. Taigi 2010 metų vasario mèn. peržiūrètos PSO pandeminio A(H1N1) gripo ir kitu gripo virusų gydymo rekomendacijos skelbia, kad ir vėliau nei per 48 val. hospitalizuotiems ligoniams, kuriems kliniškai ittariamas ar laboratoriškai patvirtintas pandeminis gripas, rekomenduojamas antivirusinis gydymas [20].

Pandeminio gripo virusas nustatomas paèmus mégini iš nosiaryklès ir ji ištyrus. Mègini geriausia paimti 4-5 ligos dieną, kada ligonis labiausiai skleidžia virusą. Gydymas turi būti skiriamas nesulaukus laboratorinio gripo diagnozès patvirtinimo, nes tai gali užtrukti, arba greito testo atsakymas gali būti klaidingai neigiamas. Akcentuojama, kad pavèlavus skirti gydymą gali padidèti sunkios būklès, būtinybès taikyti intensyviąją terapiją ir mirties rizika [25]. 
2010 m. vasario mèn. atnaujintose PSO gripo gydymo rekomendacijose nustatytos pacientų rizikos grupés, kuriems, įtariant gripą, nedelsiant turi būti skirtas antivirusinis gydymas (4 lentelè) [20].

Nustatytos ir pacientų, kuriems įtariamas gripas, kategorijos bei rekomenduojamas veiksmų planas (5 lentelè).

PSO rekomendacijose taip pat nurodomi sunkios eigos gripo ar greito progresavimo simptomai, kuriems esant pacientas turi būti nedelsiant hospitalizuojamas ir pradètas gydyti antivirusiniais vaistais. Tai turi būti atliekama, kai mažesnę nei $38^{\circ} \mathrm{C}$ temperatūrą lydi:

- dispnèja ar pasunkejjęs kvejpavimas;

- hipoksija $\left(\mathrm{SpO}_{2} \leq 92\right.$ proc.) tiekiant $\mathrm{O}_{2}$;

- tachipneja;

- arterinè hipotenzija;

- tachikardija;

- susijaudinimas ar mieguistumas;

- sunki dehidratacija (> 10 proc. kūno masès, silpni periferiniai pulsai, blogas odos turgoras, neišmatuojamas AKS, pailgèjęs KPS);

- pokyčiai krūtinès ląstos rentgenogramoje (infiltraciniai pokyčiai);

- pakartotinè karščiavimo banga;

- pacientas iš prastos socialinès aplinkos.

Naujose PSO pandeminio gripo gydymo rekomendacijose pateikiama nekomplikuotos ir komplikuotos eigos gripo gydymo taktika [20]. Atkreipiamas demesys, kad naujagimiai ir kūdikiai iki 2 metų amžiaus taip pat gali būti gydomi antivirusiniais preparatais (6, 7 lentelès)

7 lenteleje pateiktos gydymo oseltamiviru rekomendacijos skirtos visiems vaikams ir kūdikiams. Mažų vaikų gripui gydyti rekomenduojama oseltamiviro suspensija. Jei jos nèra, galima skirti kapsulių. Kapsulè gali būti atidaryta ir prieš pat vartojimą turinys praskiestas saldžiu skysčiu ar įdètas $i$ minkštos konsistencijos maistą. Reikia žinoti, kad mažiems vaikams skiriant kapsules galima tikètis daugiau nepageidaujamų reiškinių (dažniausiai - vėmimo) [16, 20].

Nors dažniausiai rekomenduojamas 5 dienu oseltamiviro kursas, sunkių būklių atveju vyresniems vaikams ir suaugusiesiems gali būti skiriama padidinta dozè (iki $150 \mathrm{mg} 2 \mathrm{k} . / \mathrm{d}$. suaugusiesiems) ilgesniais (10 dienų) kursais [22].

Duomenų apie vaikų gydymą ị veną švirkščiamu zanamiviru ir peramiviru nepakanka. Inhaliuojamųjų miltelių pavidalo zanamiviro gali būti skiriama vaikams nuo $5 \mathrm{~m}$. amžiaus. Zanamiviras turi laktozès ir negali būti ịkvepiamas per nebulaizeri. Plataus spektro antivirusinis vaistas aerozolinis ribavirinas, vartojamas per nebulaizeri, gali būti skiriamas suaugusiesiems, sergantiems A ir B gripu. Vaikų gripui gydyti šis preparatas nepatvirtintas.

Simptominis vaiku gripo gydymas apima bendrąsias karščiavimo bei dehidratacijos ir hipoksijos korekcijos priemones:

- Antipiretikai (paracetamolis, nesteroidiniai vaistai nuo uždegimo, pvz., ibuprofenas).

- Adekvati rehidratacija geriamaisiais ir i̇ veną leidžiamais tirpalais.

- Deguonies terapija (nosies kaniulès, kaukè, kaukè su rezervuaru, intubacija, ventiliacija).

- Profilaktika antibiotikais nerekomenduojama.
4 lentelè. PSO nustatytos pacientų gripo rizikos grupès

- Kūdikiai ir vaikai, ypač iki $2 \mathrm{~m}$. amžiaus

- Nèščios moterys

- Bet kokio amžiaus asmenys, sergantys lètinėmis plaučių ligomis (astma, LOPL)

- Bet kokio amžiaus asmenys, sergantys lètinèmis širdies ligomis (lètiniu širdies nepakankamumu)

- Asmenys, sergantys metabolinėmis ligomis (pvz., CD)

- Asmenys, sergantys lètinėmis inkstų, kepenų, nervų sistemos ligomis (nervų-raumenų, psichomotorinès raidos sutrikimų, neiskaitant autizmo)

- Asmenys, kuriems nustatytos pirminès (ŽIV) ir antrinės imunosupresinès būklès, navikinès ligos, skiriamas imunosupresinis gydymas, diagnozuota hemoglobinopatija

- Vaikai iki 18 metuc, kuriems taikomas ilgalaikis gydymas aspirinu

- Vyresni kaip 65 m. amžiaus asmenys

5 lentelè. Pacientų, kuriems įtariamas gripas, kategorijos ir rekomenduojamas veiksmu planas pagal PSO

\begin{tabular}{|c|c|c|}
\hline A kategorija & B kategorija & C kategorija \\
\hline $\begin{array}{l}\text { - Neaukšta } \\
\text { temperatūra ir ko- } \\
\text { sulys ir/ar gerklès } \\
\text { skausmas } \\
\text { - Gali būti galvos } \\
\text { ar viso kūno } \\
\text { skausmai } \\
\text { Vèmimas, viduria- } \\
\text { vimas }\end{array}$ & $\begin{array}{l}\text { - Febrilus karščiavi- } \\
\text { mas ir labai ryškūs } \\
\text { simptomai A kate- } \\
\text { gorijos pacientams } \\
\text { Rizikos grupès } \\
\text { pacientai: } \\
\text { - } \quad \text { vaikai iki } 5 \mathrm{~m} \text {. } \\
\quad \text { amžiaus } \\
\text { - } \quad \text { sergantieji lèti- } \\
\text { nėmis ligomis } \\
\text { ir imunosupre- } \\
\text { sinès būklès } \\
\text { pacientai }\end{array}$ & $\begin{array}{l}\text { - Jei greta A ir B kategori- } \\
\text { joms būdingų požymių } \\
\text { yra vienas ir daugiau iš } \\
\text { šių simptomų: } \\
\text { - } \quad \text { pasunkèjęs alsavi- } \\
\text { mas, dusulys, krūti- } \\
\text { nès ląstos skausmas, } \\
\text { kraujo atkosèjimas, } \\
\text { pakitusi nagų spalva } \\
\text { (melsvumas) } \\
\text { mieguistumas, } \\
\text { sumažèjęs AKS } \\
\text { dirglumas, atsi- } \\
\text { sakymas valgyti } \\
\text { (mažiems vaikams) } \\
\text { paūmèjusi lètinè liga }\end{array}$ \\
\hline \multicolumn{3}{|l|}{ Veiksmų planas } \\
\hline $\begin{array}{l}\text { Pacientai gali būti } \\
\text { gydomi namuose, } \\
\text { izoliuoti nuo kitų } \\
\text { asmenų } \\
\text { - } \\
\text { Antivirusinių } \\
\text { vaistų neskiriama } \\
\text { - Simptominis } \\
\text { gydymas } \\
\text { Tyrimai gripo } \\
\text { virusui verifikuoti } \\
\text { (H1N1) nereika- } \\
\text { lingi } \\
\text { Pakartotinė gydy- } \\
\text { tojo apžiūra per } \\
24-48 \text { val. }\end{array}$ & $\begin{array}{l}\text { Pacientai gali būti } \\
\text { gydomi namuose, } \\
\text { izoliuoti nuo kitų } \\
\text { asmenų } \\
\text { Skiriama anti- } \\
\text { virusinių vaistuc } \\
\text { (oseltamiviro/ } \\
\text { zanamiviro) } \\
\text { Simptominis } \\
\text { gydymas } \\
\text { Tyrimai gripo } \\
\text { virusui verifikuoti } \\
\text { (H1N1) nereikalingi } \\
\text { Pakartotinè gydy- } \\
\text { tojo apžiūra per } \\
\text { 24-48 val. }\end{array}$ & $\begin{array}{ll}\text { - } & \text { Pacientai hospitalizuo- } \\
\text { - } & \text { Skmi } \\
\text { vairiama antivirusinių } \\
\text { zaistu (oseltamiviro/ } \\
\text { - } \quad \text { Simamiviro) } \\
\text { - Tyrimai gripo virusui } \\
\text { verifikuoti (H1N1) } \\
\text { nereikalingi. }\end{array}$ \\
\hline
\end{tabular}

- Esant antrinei bakterinei infekcijai - antibakterinis gydymas, skiriamas pagal visuomeneje igytos pneumonijos gydymo rekomendacijas ir pasėlių rezultatus.

Papildomos rekomendacijos [3, 20, 26]:

- Vaiku ir paaugliuc iki 18 m., sergančiuc patvirtintu ar kliniškai ịtariamu gripu, negalima gydyti salicilatais (aspirinu) dèl Reye sindromo rizikos.

- Nerekomenduojama vaikams iki $4 \mathrm{~m}$. amžiaus skirti dideles vaistų nuo peršalimo (sudètinių preparatų, i kurių sudètį įeina pseudoefedrino) dozes, prieš tai nepasitarus su gydytoju [3]. 
6 lentelè. PSO rekomenduojamas pandeminio gripo gydymas

\begin{tabular}{|c|c|c|}
\hline Pacientai & $\begin{array}{l}\text { Pandeminis } 2009 \\
\text { m. H1N1 ar } \\
\text { sezoninis gripas }\end{array}$ & $\begin{array}{l}\text { Žinomas ar įtaria- } \\
\text { mas atsparumas } \\
\text { oseltamivirui }\end{array}$ \\
\hline \multicolumn{3}{|c|}{ Nekomplikuota ligos eiga } \\
\hline $\begin{array}{l}\text { Rizikos grupés } \\
\text { pacientai }\end{array}$ & $\begin{array}{l}\text { Kuo ankstyvesnis gy- } \\
\text { dymas oseltamiviru } \\
\text { ar zanamiviru }\end{array}$ & $\begin{array}{l}\text { Kuo anksčiau } \\
\text { pradèti gydymą } \\
\text { zanamiviru }\end{array}$ \\
\hline \multicolumn{3}{|c|}{ Sunki ar progresuojanti ligos eiga } \\
\hline $\begin{array}{l}\text { Visi pacientai (vaikai } \\
\text { ir suaugusieji) }\end{array}$ & $\begin{array}{l}\text { Kuo anksčiau } \\
\text { pradèti gydymą osel- } \\
\text { tamiviru. Zanami- } \\
\text { virą skirti tik nesant } \\
\text { oseltamiviro }\end{array}$ & $\begin{array}{l}\text { Kuo anksčiau } \\
\text { pradèti gydymą } \\
\text { zanamiviru }\end{array}$ \\
\hline $\begin{array}{l}\text { Imunosupresinės } \\
\text { būklės pacientai }\end{array}$ & $\begin{array}{l}\text { Kuo greičiau pradèti } \\
\text { gydymą oseltamivi- } \\
\text { ru. Spręsti dèl dides- } \\
\text { nių dozių ir ilgesnès } \\
\text { gydymo trukmès }\end{array}$ & $\begin{array}{l}\text { Kuo anksčiau } \\
\text { pradèti gydymą } \\
\text { zanamiviru }\end{array}$ \\
\hline
\end{tabular}

7 lentelè. PSO rekomenduojamos antivirusinių vaistų dozės kūdikiams ir vaikams

\begin{tabular}{|c|c|c|c|c|}
\hline \multirow[t]{2}{*}{ Vaistas } & \multicolumn{4}{|c|}{ Amžiaus grupès (dienomis, mėnesiais) } \\
\hline & $>14 \mathrm{~d}$ & 14 d. -3 mèn. & 3-5 mèn. & 6-11 mèn. \\
\hline \multicolumn{5}{|c|}{ Oseltamiviras (Tamiflu) } \\
\hline 5 dienos & $\begin{array}{l}3 \mathrm{mg} / \mathrm{kg} / \\
\text { dozei x } 1 \\
\text { k./d. }\end{array}$ & $\begin{array}{l}12 \mathrm{mg} \times 2 \\
\mathrm{k} . / \mathrm{d} .(3 \mathrm{mg} / \\
\mathrm{kg} / \text { dozei x } 2 \\
\text { k./d.) }\end{array}$ & $\begin{array}{l}20 \mathrm{mg} x \\
2 \mathrm{k} . / \mathrm{d} .(3 \\
\mathrm{mg} / \mathrm{kg} / \\
\text { dozei x } 2 \\
\mathrm{k} . / \mathrm{d} .)\end{array}$ & $\begin{array}{l}25 \mathrm{mg} x \\
2 \mathrm{k} . / \mathrm{d} .(3 \\
\mathrm{mg} / \mathrm{kg} / \\
\text { dozei x } 2 \\
\mathrm{k} . / \mathrm{d} .)\end{array}$ \\
\hline \multirow[t]{2}{*}{ Vaistas } & \multicolumn{4}{|c|}{ Amžiaus grupès (metais) } \\
\hline & $1-5 \mathrm{~m}$ & $5-9 \mathrm{~m}$. & $10-12 \mathrm{~m}$. & $13-64 \mathrm{~m}$. \\
\hline \multicolumn{5}{|c|}{ Oseltamiviras (Tamiflu) } \\
\hline 5 dienos & \multicolumn{3}{|c|}{$\begin{array}{l}\leq 15 \mathrm{~kg}-30 \mathrm{mg} \times 2 \mathrm{k} . / \mathrm{d} . \\
>15-23 \mathrm{~kg}-45 \mathrm{mg} \times 2 \mathrm{k} . / \mathrm{d} . \\
>23-40 \mathrm{~kg}-60 \mathrm{mg} \times 2 \mathrm{k} . / \mathrm{d} . \\
>40 \mathrm{~kg}-75 \mathrm{mg} \times 2 \mathrm{k} . / \mathrm{d} .\end{array}$} & $\begin{array}{l}75 \mathrm{mg} \times 2 \\
\mathrm{k} . / \mathrm{d} .\end{array}$ \\
\hline \multicolumn{5}{|c|}{ Zanamiviras (Relenza) } \\
\hline 5 dienos & $\begin{array}{l}\text { Nereko- } \\
\text { menduo- } \\
\text { jama }\end{array}$ & $\begin{array}{l}10 \mathrm{mg} \\
(2 \text { inhaliaci- } \\
\text { jos }) \times 2 \mathrm{k} . / \mathrm{d} .\end{array}$ & $\begin{array}{l}10 \mathrm{mg} \\
(2 \text { inhalia- } \\
\text { cijos }) \times 2 \\
\text { k./d. }\end{array}$ & $\begin{array}{l}10 \mathrm{mg} \\
(2 \text { inhalia- } \\
\text { cijos }) \times 2 \\
\text { k./d. }\end{array}$ \\
\hline
\end{tabular}

- Sunkaus gripo ir progresuojančio virusinio pneumonito atvejais esant respiracinio distreso simptomams ar kvépavimo nepakankamumui rutiniškai sisteminiai gliukokortikoidai neskirtini, nebent yra kitų indikacijų.

\section{GRIPO PROFILAKTIKA}

Pandeminio A(H1N1) gripo viruso vakcinos registruotos keliose šalyse: Australijoje, Kinijoje, JAV. Europos Sąjungoje po teigiamo Medicininių produktų, skirtų naudoti žmonėms, komiteto mokslinio įvertinimo Europos vaistų vertinimo agentūroje (EMEA) užregistruotos trys pandeminio gripo vakcinos: „Focetria“" (gamintojas „Novartis“), „Pandemrix “ (gamintojas „GlaxoSmithKline“) ir „Celvapan $^{\otimes}$ (gamintojas „Baxter"). Šias gripo vakcinas leidžiama naudoti visose ES šalyse, Islandijoje, Lichtenšteine ir Norvegijoje. Vengrijoje užregistruota vietinių gamintojų pagaminta pandeminio gripo vakcina „Omninvest“, kuria gali būti skiepijama tik Vengrijoje.

Pasaulyje jau išplatinta $350 \mathrm{mln}$. A(H1N1) gripo vakcinos dozių, Europoje - 58,2 mln. dozių. Europoje iš $53 \mathrm{PSO}$ valstybių 40 skiepijo savo piliečius nuo pandeminio gripo, skiepijimo mastas - nuo 8 iki 70 proc. gyventoju [19].

Sprendimus, kokios gyventoju grupès bus skiepijamos pandeminio gripo vakcina, priima kiekviena šalis. JAV Atlantos ligų kontrolès centro ekspertai pirmiausia rekomenduoja skiepyti labiausiai pažeidžiamu grupių gyventojus: něščiąsias, asmenis, kurie augina vaikus iki 6 mèn. amžiaus ar gyvena kartu su jais, medicinos darbuotojus, vaikus nuo 6 mèn. amžiaus ir jaunus suaugusiuosius iki $24 \mathrm{~m}$., taip pat bet kurio amžiaus asmenis, priskiriamus rizikos grupei gripo komplikacijoms išsivystyti (4 lentelè) [3, 27, 22].

Tiek sezoninio, tiek ir pandeminio gripo vakcinos gali būti dvejopos. Dažniau naudojamos negyvųjų gripo virusų vakcinos. Jos yra švirkščiamos ị žastą. Mažiems vaikams šias vakcinas rekomenduojama švirkšti i šlaunị. Kitas vakcinų tipas - gyvųjų virusų vakcinos, kurios ipurškiamos ì nosi $[21,22]$.

Negyvosiomis gripo vakcinomis negali būti skiepijami:

- asmenys, tureję anafilaksinių ar kitų gyvybei pavojingu alerginių reakcijų i bet kurị vakcinos komponentą;

- asmenys, patyrę kitokių sunkių nepageidaujamų reakcijuc skiepijant gripo vakcina;

- asmenys, kuriems per 6 savaites po skiepijimo gripo vakcina išsivystè Guillain-Barre sindromas (ūminè autoimuninè poliradikuloneuropatija);

- vaikai iki 6 mèn. amžiaus (šiai amžiaus grupei negyvųjų vakcinų naudojimas nepatvirtintas);

- asmenys, vakcinacijos dieną sergantys vidutinio sunkumo ar sunkia liga (karščiuojantys). Juos bus galima skiepyti, kai pasveiks.

PSO informaciniame $2009 \mathrm{~m}$. pranešime skelbiama, kad, atsižvelgiant i skiepijimo apimtis, nors ir retai, bet gali pasireikšti nepageidaujamos reakcijos, kurių neįmanoma prognozuoti net vykdant plačius klinikinius tyrimus. Kaip tikètasi, dažniausios nepageidaujamos reakcijos - injekcijos vietos patinimas, paraudimas ar skausmas, paprastai netrukus praeinantis savaime. Kai kurie paskiepyti asmenys skundèsi karščiavimu, galvos skausmu, nuovargiu ir raumenu skausmu, bet tokie atvejai reti. Šie simptomai dingsta savaime, dažniausiai per 48 valandas. Be to, registruota ịvairių alerginių reakcijų. Ju dažnumas nèra didesnis, nei tikètasi. Labiausiai baiminamasi povakcininio Guillain-Barre sindromo. PSO skelbia, kad negavo nè vieno pranešimo apie paskiepyto asmens, kuriam pasireiškė Guillain-Barre sindromas, mirties atveji. Visi pacientai pasveiko.

Visi mirties atvejai, apie kuriuos buvo pranešta, PSO kruopščiai tiriami. Nors kai kurie tyrimai dar nebaigti, atliktųjų rezultatai padejjo atmesti tikimybę, kad ligoniai mirè būtent nuo pandeminių skiepų. Pavyzdžiui, Kinijoje paskiepyta daugiau nei $11 \mathrm{mln}$. žmonių. Nacionalinès sveikatos apsaugos institucijos PSO pranešẻ apie 15 sunkaus nepageidaujamo poveikio atvejų ir du mirties atvejus. Ištyrus šiuos mirties atvejus bei įvertinus skrodimo rezultatus nustatyta, kad mirties priežastis buvo ne vakcina, bet ligonio sveikatos būklè. 
Nè viena vakcina, taip pat ir pandeminio gripo, neapsaugo nuo susirgimo 100 proc. Bet jos ženkliai sumažina riziką susirgti. Po paskiepijimo imunitetas susidaro per 14 dienų. Tačiau pirmieji imuniniai procesai suaktyvinami jau per 2-3 dienas po vakcinos suleidimo [21, 22]. Užsikrètusieji per 1-3 dienas po vakcinacijos, gali susirgti.

Suaugusiesiems ir vyresniems nei 10 metu vaikams ekspertai rekomenduoja vieną vakcinos dozę. Dar nepakanka studijų patvirtinti, kiek dozių turètų būti skiriama imunosupresinès būklès pacientams. Vaikams nuo 6 mèn. iki 10 metų amžiaus taip pat rekomenduojama viena vakcinos dozè, tačiau ši rekomendacija gali būti pakeista atsižvelgiant ì naujų studijų rezultatus [21].

\section{APIBENDRINIMAS}

Nors daugeliu atvejų 2009 metų pandeminio A(H1N1) gripo klinikinè eiga lengva, vis dèlto vaikams liga gali būti sunki, ypač mažiems ir lètinèmis plaučių bei kitomis ligomis sergantiems pacientams. Daugeliui vaiku gripas pasireiškia tipiniais simptomais: karščiavimu, kosuliu, rinorèja ir gerklès skausmu. Vaikams būdingi ir virškinamojo trakto simptomai: vėmimas ir viduriavimas. Galimos sunkios gripo komplikacijos, dažniausiai pasireiškiančios kvėpavimo sistemoje ir sukeliančios kvėpavimo nepakankamumą, šoką ir mirtį. Sunkaus komplikuoto gripo gydymas turi būti intensyvus ir agresyvus. Anksti pradètas gydymas neuraminidazès inhibitoriais (oseltamiviru) gali būti efektyvus. Vaikams, kuriems gripas komplikavosi bakterine infekcija, antibakterinis gydymas yra būtinas ir gali būti gyvybiškai svarbus.

Vakcinacijos reikšmė apsaugant nuo sezoninio ar pandeminio gripo yra neabejotina. Nacionalinio gripo forumo metu ekspertai teigè, kad tikètina ir antra pandeminio gripo banga, taigi vakcinacijos klausimas tebèra aktualus.

\section{LITERATŪRA}

1. Jonathan Dushoff, Joshua B. Plotkin, Cecile Viboud, Lone Simonsen et al. Mortality due to Influenza in the United States-An Annualized Regression Approach Using Multiple-Cause Mortality Data; American Journal of Epidemiology 2006 163(2):181-187.

2. Thompson WW, Shay DK, Weintraub E, Brammer L, Cox N, Anderson LJ, Fukuda K., Mortality associated with influenza and respiratory syncytial virus in the United States; JAMA. 2003 Jan 8;289(2):179-86.

3. Halasa Natasha B., Update on the 2009 pandemic influenza A H1N1 in children, Current Opinion in Pediatrics: February 2010, Vol. 22, Issue 1, p 83-87.

4. Swine influenza $A(H 1 N 1)$ infection in two children: Southern California, March-April 2009. MMWR Morb Mortal Wkly Rep 2009; 58:400-402. This is the first description of two cases of 2009 pandemic influenza A H1N1 infection.

5. Dawood FS, Jain S, Finelli $L$, et al. Emergence of a novel swine-origin influenza A (H1N1) virus in humans. N Engl J Med 2009; 360:2605-2615.

6. Perez-Padilla R, de la Rosa-Zamboni D, Ponce de Leon $\mathrm{S}$, et al. Pneumonia and respiratory failure from swine-origin influenza $A(H 1 N 1)$ in Mexico. $N$ Engl J Med 2009; 361:680-689.

7. Outbreak of swine-origin influenza $A(\mathrm{H} 1 \mathrm{~N} 1)$ virus infection: Mexico, March-April 2009. MMWR Morb Mortal Wkly Rep 2009; 58:467-470.

8. World Health Organization. 10 October 2009; http://www.who.int/csr/ disease/swineflu/4th_meeting_ihr/en/index.html 2009. [DG Statement following the meeting of the Emergency Committee].

9. Jain S, Kamimoto L, Bramley AM, et al. Hospitalized patients with $2009 \mathrm{H} 1 \mathrm{~N} 1$ influenza in the United States, April-June 2009. N Engl J Med 2009; 361:1935-1944.

10. Prevention CfDCa. Novel H1N1 flu: facts and figures. 200911 October; http:// www.cdc.gov/H1n1flu/surveillanceqa.htm. [Novel H1N Confirmed and Probable Case Rate in the United States, By Age Group] [Accessed 11 October 2009].

\section{INFLUENZA IN CHILDREN - LESSONS OF 2009}

\author{
LAIMUTÉ VAIDELIENÉ, DOVILE GRINKEVIČIÜTÉ \\ DEPARTMENT OF CHILDREN DISEASES \\ LITHUANIAN UNIVERSITY OF HEALTH SCIENCES
}

Keywords: pandemic flu, H1N1, children, epidemiology, clinical signs, treatment, prevention.

Summary. In 2009 global influenza H1N1 virus has spread, so far the damage was done less, as was expected. Pandemic started in developed countries, influenza was not so dangerous for older people, as 1918 - the latter already had immunity, antiviral drugs worked, and most of patients had not felt very severe symptoms. Influenza H1N1 was recorded in 214 countries of the world, 1483520 cases of influenza registered and 18 036 deaths of pandemic influenza cases were confirmed in the laboratory. 59 thousand Lithuanian adults and children had flu symptoms from $0 c-$ tober 2009 to March 2010. Laboratory confirmed 810 A (H1N1) influenza cases, 23 deaths were recorded. Children morbidity data are not anounced yet. 545 children having clinical symptoms of influenza, were treated in Clinic of children diseases of Kaunas University of medicine and in the II Clinical hospital of Kaunas from 06.11.2009 to 22.12.2009. 16 children required supervision at intensive care unit, six children died due to suspected pandemic influenza or its complications, laboratory confirmed H1N1 virus in two of them. Clinical symptoms of influenza in Kaunas children were similar to the WHO declared pandemic flu symptoms. Fever was reported in 99.45 proc., cough - in 80.37 proc., runny nose - in 45.32 proc., headache - in 26,97 proc., sore throat - in 18.17 proc. of cases. Specific symptoms of pandemic H1N1 influenza - vomiting and diarrhea were registered as well (5,32 proc., and 8.81 proc. of children respectively). 18,7 proc. of children had signs of cytopenia: leukopenia - 11.7 proc., granuliopenia - 9.1 proc., thrombopenia - 12.5 proc. of children. These children more often had bacterial infection (11.1 proc.) in comparison with children without cytopenia (1.9 proc. $X 2=16.4, p$ $<0.05)$. The most frequent complication - pneumonia, was diagnosed in 134 (24.59 proc.) hospitalized children.

Severe flu complications, usually manifesting in respiratory system and causing respiratory failure, shock, and lethal option are possible. Therefore in February 2010 WHO updated recommendations for high-risk patients, who should get antiviral treatment as soon as possible. Inhaled zanamivir and oral oseltamivir were approved for the treatment of influenza and prevention in children. Antiviral medications, started within 48 hours from onset, reduces disease severity and duration. This year's experience showed, that antiviral therapy may be beneficial, even started later. 225 children (41.3 proc.), treated in both Kaunas hospitals received oseltamivir. When children with influenza are complicated by bacterial infection, antibacterial therapy is essential and can be vital. 249 (53,9 proc.) children at Kaunas hospitals were treated with antibiotics. Importance of vaccination to protect against seasonal and pandemic influenza, is undeniable. However, only 6 (1,1 proc.) children, hospitalized at KMU Children clinic and the II Kaunas hospital were vaccinated against seasonal flu. Experts say, that the possibility of the second pandemic influenza wave more likely. In this case, the vaccination question also remains relevant. 